ISSN 0258-7122

Bangladesh J. Agril. Res. 39(1): 113-125, March 2014

\title{
ADOPTION OF MUNGBEAN TECHNOLOGIES AND TECHNICAL EFFICIENCY OF MUNGBEAN (Vigna radiata) FARMERS IN SELECTED AREAS OF BANGLADESH
}

\author{
M. A. HAQUE ${ }^{1}$, M. A. MONAYEM MiaH ${ }^{2}$ \\ A. M. $\mathrm{ALI}^{3}$ AND A. N. LUNA ${ }^{4}$
}

\begin{abstract}
Mungbean is one of the most important pulse crops in Bangladesh. The demand of mungbean is very high due to its good taste. To date, different national institutes released 14 improve mungbean varieties with complete package of technologies and disseminated them to the farmers. But, the farm level adoption of mungbean varieties, their economics, and farmer's efficiencies are not well known to the researchers and policy planners. Therefore, the study assessed the farm level adoption of mungbean technologies, technical efficiency of mungbean growers, and find out constraints to its higher production. Data were collected from 283 randomly selected mungbean farmers from Jessore, Kushtia, and Barisal districts during March-April 2009. The highly adopted mungbean varieties were BARI Mung-3, 4 and 5. Technologies, such as ploughing, weeding, and seed rate occupied higher level of adoption. Sowing time and insect-pest control were medium level and irrigation was lower level adoption. In case of chemical fertilizer, urea secured higher level of adoption followed by TSP and MoP. The yield and net return of mungbean was $1196 \mathrm{~kg}$ and Tk. 15678 per hectare, respectively. The benefit cost ratio was 1.69 and 2.47 on full cost and cash cost basis, respectively. About $67 \%$ farmers achieved more than $90 \%$ technical efficiency level. Twenty eight percent farmers' technical efficiency level, between $81-90 \%$ and the rest $5 \%$ farmers' technical efficiency level was less than $80 \%$. Diseases and pest infestation, lack of good quality seed, lack of knowledge about improved technologies were the major constraints to mungbean cultivation. Government should provide hand-on training and distribute quality seed to the farmers for increasing the area of mungbean cultivation.
\end{abstract}

Keywords: Mungbean, adoption, technical efficiency.

\section{Introduction}

Pulses are the most important protein in the diet of the majority of the people of Bangladesh. It contains about twice as much protein as cereals. It also contains amino acid lysine, which is generally deficit in food grains (Islam, 2007). Pulse bran is also used as quality feed for animals. Apart from these, the ability to fix

${ }^{1}$ Principal Scientific Officer, ${ }^{2}$ Senior Scientific Officer, Agricultural Economics Division, Bangladesh Agricultural Research Institute (BARI), Gazipur, ${ }^{3}$ Professor, Department of Economics, Jahangir Nagor University, Savar, Dhaka, and ${ }^{4}$ MSS Student, Department of Economics, Lalmatia Mohilla University College, Dhaka, Bangladesh. 
nitrogen and addition of organic matter to the soil are important factors in maintaining soil fertility (Senanayake et al., 1987; Zapata et al., 1987). In the existing cropping systems, pulses fit well due to its short duration, low input, minimum care required and drought tolerant nature. Among the food legumes grown, lathyrus, lentil, chickpea, blackgram, and mungbean are the major and they contribute more than $95 \%$ to the total pulses production in the country (Rahman 1998). The present production of pulses can meet not more than $30 \%$ of the total national demand (Afzal and Bakar 2004). The rest $70 \%$ is being met up in every year by importing pulses using valuable foreign currencies.

Mungbean (Vigna radiate L.) is grown round the year (Three times) in Bangladesh. It provides grain for human consumption as it contains $19.5 \%$ to $28.5 \%$ protein (AVRDC, 1988). Mungbean supplies a substantial amount of nitrogen to the succeeding non-legume crops (i.e., rice) grown in rotation (Sharma and Prasad 1999). Currently, this crop is being cultivated after harvesting of Rabi crops (i.e., wheat, mustard, lentil, etc.). As a short duration crop, it can be fitted in as a cash crop between major cropping seasons. The present area under mungbean cultivation is 27.44 thousand ha with a total production of 19.45 thousand tons and an average yield of $0.708 \mathrm{t} / \mathrm{ha}$ (BBS, 2011). In spite of various positive sides, most of the mungbean areas are replaced by cereals (Abedin and Anwarul, 1991). The growth rates of production and yield are positive and highly significant but the growth rate of its area is less than half $(0.32 \%)$ during 1982-2011. The area growth rates were even negative during 1992-01 and 2002-11 (Table 1).

Fourteen varieties of mungbean have been developed by different institutes like Bangladesh Agricultural Research Institute (BARI), Bangladesh Institute of Nuclear Agriculture (BINA), and Bangabadhu Sheikh Muzibur Rahman Agricultural University (BSMRAU) and disseminated them with the complete package of management technologies to the farmers for cultivation. Mungbean cultivation is gaining popularity among the farmers day by day. But, the farm level adoption of mungbean technologies, their economics at farm level, and farmer's technical efficiencies in cultivating the crop are not well known to the researchers and policy planners. Therefore, an attempt was made to study this important crop with the following objectives.

(i) to know the level of adoption of improved mungbean varieties and their management technologies at farm level;

(ii) to estimate the cost and return of mungbean cultivation;

(iii) to measure the technical efficiency of mungbean growers; and

(iv) to identify the constraints to mungbean cultivation and suggest remedial measures for its improvement. 
Table 1. Mean, coefficient of variation and growth rates of area, production, and yield of mungbean in different periods.

\begin{tabular}{|c|c|c|c|c|}
\hline Period & Mean & STD & $\mathrm{CV}(\%)$ & Growth rate $(\%)$ \\
\hline \multicolumn{5}{|l|}{ Area (ha) } \\
\hline $1982-91$ & 36834 & 22805 & 162 & $20.54 * * *$ \\
\hline 1992-01 & 54527 & 1005 & 5426 & -0.00 \\
\hline $2002-11$ & 30129 & 10053 & 300 & $-7.58 * *$ \\
\hline 1982-11 & 40497 & 17397 & 233 & 0.32 \\
\hline \multicolumn{5}{|c|}{ Production (ton) } \\
\hline 1982-91 & 20271 & 12366 & 164 & $19.75 * * *$ \\
\hline 1992-01 & 32731 & 1753 & 1867 & $1.43 * * *$ \\
\hline $2002-11$ & 23599 & 6681 & 353 & $-7.40 * * *$ \\
\hline $1982-11$ & 25534 & 9538 & 268 & $1.93 * *$ \\
\hline \multicolumn{5}{|l|}{ Yield (t/ha) } \\
\hline 1982-91 & 0.556 & 0.032 & 1727 & -0.73 \\
\hline 1992-01 & 0.600 & 0.036 & 1661 & $1.44 * * *$ \\
\hline $2002-11$ & 0.804 & 0.165 & 486 & 0.18 \\
\hline $1982-11$ & 0.653 & 0.146 & 449 & $1.61 * * *$ \\
\hline
\end{tabular}

Source: Using various issues of BBS

\section{Materials and Method}

Sampling technique: A multi-stage sampling technique was followed in this study to select study areas and sample farmers. In first stage of sampling, three mungbean growing districts, namely Jessore, Kushtia, and Barisal were selected purposively. In the second stage, one Upazila was selected from each district for sample survey. The names of the Upazilas were Jhekorgacha Upazila under Jessore district, Bharamara Upazila under Kushtia district and Uzirpur Upazila under Barisal district. In the third stage, a total of 283 mungbean farmers were selected by random sampling technique.

Method of data collection and period of study: Data for the present study were collected from sample mungbean farmers through face to face interview method using a pre-tested interview schedule. Field level primary data were collected by the researcher with the help of trained enumerators for the period of March-April, 2009.

Analytical techniques: Both fixed cost and variable cost were taken into account in calculating cost of mungbean cultivation. Land use cost was calculated on the basis of per year existing lease value of land. The profitability of mungbean cultivation was examined on the basis of gross margin, net return and benefit cost 
analysis. The mungbean cultivating farmers were classified into three categories for determining the adoption level of technologies in terms of variety, management technologies, and input use of mungbean. The categories were developed based on the mean index of the farmer with respect to each technology. A higher index indicates a higher level adoption, while a lower index indicates a lower level adoption of a technology. Adoption level was categorized for mean index > 100 as over use, (70-100) as high, (50-69) as medium, and < 50 as low. The stochastic Cobb-Douglas production frontier model was used for estimating technical efficiency of mungbean producer in the study areas

The empirical Cobb-Douglas stochastic frontier production function with double log form can be expressed as:

$$
\begin{gathered}
\ln Y_{1}=\beta_{0}+\beta_{1} \operatorname{Ln} X_{1 i}+\beta_{2} \operatorname{Ln} X_{2 i}+\beta_{3} \operatorname{Ln} X_{3 i}+\beta_{4} \operatorname{Ln} X_{4 i}+\beta_{5} \operatorname{Ln} X_{5 i}+\beta_{6} \operatorname{Ln} X_{6 i}+\beta_{7} \operatorname{Ln} X_{7 i} \\
+\quad \eta_{1} D_{1 i}+\eta_{2} D_{2 i}+\eta_{3} D_{3 i}+\eta_{4} D_{4 i}+v_{i}-u_{i}
\end{gathered}
$$

Where,

$\mathrm{Ln}=$ Natural logarithm,

$Y_{i}=$ Yield of mungbean of the $i^{\text {th }}$ farm $(\mathrm{Kg} / \mathrm{ha})$

$\mathrm{X}_{1 \mathrm{i}}=$ Human labor used of the $\mathrm{i}^{\text {th }}$ farm (man-days/ha)

$X_{2 i}=$ Ploughing cost of the $i^{\text {th }}$ farm (Tk/ha)

$\mathrm{X}_{3 \mathrm{i}}=$ Seed used by the $\mathrm{i}^{\text {th }}$ farm $(\mathrm{kg} / \mathrm{ha})$

$\mathrm{X}_{4 \mathrm{i}}=$ Farm yard manure used by the $\mathrm{i}^{\text {th }}$ farm ( $\left.\mathrm{kg} / \mathrm{ha}\right)$

$\mathrm{X}_{5 \mathrm{i}}=$ Fertilizers used by the $\mathrm{i}^{\text {th }}$ farm ( $\left.\mathrm{kg} / \mathrm{ha}\right)$

$\mathrm{X}_{6 \mathrm{i}}=$ Pesticides cost of the $\mathrm{i}^{\text {th }}$ farms $(\mathrm{Tk} / \mathrm{ha})$

$\mathrm{X}_{7 \mathrm{i}}=$ Irrigation cost of the $\mathrm{i}^{\text {th }}$ farms (Tk./ha)

$\mathrm{D}_{1 \mathrm{i}}=$ Dummy for land type of the ${ }_{\mathrm{i}}^{\text {th }}$ farm $(1=$ Medium high land, $0=$ otherwise),

$\mathrm{D}_{2 \mathrm{i}}=$ Dummy for soil type of the $\mathrm{i}^{\text {th }}$ farm ( $1=$ Sandy loam, $0=$ otherwise $)$,

$D_{3 i}=$ Dummy for sowing date of the $i^{\text {th }}$ farm (1=Optimum sowing, $o=$ Otherwise)

$\mathrm{D}_{4 \mathrm{i}}=$ Dummy for seed source of the $\mathrm{i}^{\text {th }}$ farm (1=Agriculture office, $0=$ otherwise)

$\beta$ 's and $\eta$ 's are unknown parameters to be estimated

$\mathrm{v}_{\mathrm{i}}-\mathrm{u}_{\mathrm{i}}=$ Error term

\section{Technical inefficiency effect model}

The $u_{i}$ 's in equation (2) are non-negative random variables, called technical inefficiency effects, assumed to be independently distributed such that the 
technical inefficiency effects for the $\mathrm{i}^{\text {th }}$ farmer, $\mathrm{u}_{\mathrm{i}}$, are obtained by truncation of normal distribution with mean zero and variance $\sigma_{u}^{2}$, such that

$u_{i}=\delta_{0}+\delta_{1} z_{1 i}+\delta_{2} z_{2 i}+\delta_{3} z_{3 i}+\delta_{4} z_{4 i}+\delta_{5 z 5 i}+\delta_{6} z_{6 i}+\delta_{7} z_{7 i}+W_{i}$

Where,

$\mathrm{z}_{1 \mathrm{i}}=$ Age of the farm operator of the $\mathrm{i}^{\text {th }}$ farm (years)

$\mathrm{z}_{2 \mathrm{i}}=$ Education level of the farm operator of the $\mathrm{i}^{\text {th }}$ farm (year of schooling)

$\mathrm{z}_{3 \mathrm{i}}=$ Family size (persons/household)

$\mathrm{z}_{4 \mathrm{i}}=$ Family income $(\mathrm{Tk} / \mathrm{yr})$

$\mathrm{z}_{5 \mathrm{i}}=$ Experience in mungbean farming (No. of years)

$\mathrm{z}_{6 \mathrm{i}}=$ Dummy for extension contact $(1=$ having contact, $0=$ otherwise $)$

$\mathrm{z} 7 \mathrm{i}=$ Dummy for mungbean training of the $\mathrm{i}^{\text {th }}$ farm $(1=$ Trained, $0=$ Otherwise)

$\delta$ 's are unknown parameters to be estimated and $W_{i}$ s are unobservable random

variables or classical disturbance term, which are assumed to be independently distributed, obtained by truncation of the normal distribution with mean zero and unknown variance, $\sigma^{2}$, such that $u_{i}$ is non-negative.

The $\beta, \eta$ and $\delta$ coefficients are unknown parameters to be estimated, together with the variance parameters, which are expressed in terms of $\gamma$ is the ratio of variance of farm specific technical efficiency to the total variance of output and has a value between zero and one.

$$
\begin{aligned}
& \sigma^{2}=\sigma_{u}^{2}+\sigma_{v}^{2} \\
& \text { and } \gamma=\sigma_{u}^{2} / \sigma^{2}
\end{aligned}
$$

The estimates for all parameters of the stochastic frontier (1.0) and inefficiency model (2.0) were estimated in a single stage by using the maximum likelihood method. The econometric computer software package FRONTIER 4.1 (Coelli and Battese, 1996) was used to estimate the parameters of stochastic frontier models.

\section{Results and Discussion}

\section{Adoption of mungbean varieties}

Table 2 showed the adoption level of different mungbean varieties. On an average, $49 \%$ farmers adopted BARI Mungbean- 5 followed by BARI Mungbean4 (24\%), BARI Mungbean-3 (11\%), BARI Mungbean-2 (6\%) and Binamoog-5 $(6 \%)$, respectively. The adoption of mungbean varieties varied from location to location. The highest number of farmers in Jessore (52\%) adopted BARI 
Mungbean-5 followed by that of Kushtia (49\%) and Barisal (47\%). On the other hand, 24\% farmers in Jessore adopted BARI Mungbean- 4 followed by that of Kushtia (24\%) and Barisal (23\%). It was found that $7 \%$ farmers in Barisal adopted Binamongg-5, followed by Kushtia (5\%) and Jessore (2\%). A small number of farmers in Kushtia and Jessore adopted BU Mungbean- 2 and 3.

Table 2. Adoption of mungbean varieties in different study areas

\begin{tabular}{l|c|c|c|c}
\hline \multicolumn{1}{|c}{} & Jessore & Kushtia & Barisal & All areas \\
\hline Variety & 8 & 4 & 7 & 6 \\
BARI Mung-2 & 12 & 11 & 9 & 11 \\
BARI Mung-3 & 26 & 24 & 23 & 24 \\
BARI Mung-4 & 52 & 49 & 47 & 49 \\
Binamng Mung-5 & - & 3 & 2 & 2 \\
Binamngg-5 & 2 & 5 & 7 & 6 \\
BU Mung-2 & - & 2 & 3 & 1 \\
BU Mung-3 & - & 2 & 2 & 1 \\
All types & 100 & 100 & 100 & 100 \\
\hline
\end{tabular}

\section{Adoption of management technology}

The existing level of technology employed in terms of agronomic practices, time of operation, and input use are essential for achieving higher yield and return. The existing levels of technology employed in the production of mungbean are presented in Table 3. Three to four times ploughing and laddering are recommended for mungbean cultivation. On an average, $84 \%$ farmers ploughed their land 3 to 4 times and only 16\% farmers ploughed their land 1 to 2 times for mungbean cultivation. Based on the adoption index, higher level adoption was occurred in ploughing and laddering. Line sowing was recommended for mungbean cultivation. Adoption of sowing seed was low in all the study areas. It was observed that $52 \%$ farmers performed weeding two times, which was recommended for mungbean cultivation and $42 \%$ farmers provided weeding one time. Based on the adoption index, the higher level of adoption was occurred in providing weeding to mungbean crop. About $65 \%$ farmers irrigated their land one time, whereas only $3 \%$ farmers irrigated their land two times. Based on the adoption index, the lower level adoption was found in the application of irrigation. In the study areas, $75 \%$ farmers used pesticides and $35 \%$ farmers did not use any pesticides in their crop. According to adoption index, medium level adoption occurred in applying pesticides to control insect-pest infestation. 
Table 3. Crop management technologies for mungbean cultivation in different study areas.

\begin{tabular}{|c|c|c|c|c|c|c|}
\hline Technology & Recommendation & Jessore & Kushtia & Barisal & All & $\begin{array}{c}\text { Adoption } \\
\text { level }\end{array}$ \\
\hline \multicolumn{7}{|l|}{$\begin{array}{l}\text { 1. No. of plowing (\% } \\
\text { responses) }\end{array}$} \\
\hline $1-2$ & & 14 & 21 & 14 & 16 & \\
\hline $3-4$ & Recommendation & 84 & 79 & 86 & 84 & \\
\hline Adoption index & & 104 & 77 & 82 & 87 & High \\
\hline \multicolumn{7}{|l|}{$\begin{array}{l}\text { 2. Sowing method (\% } \\
\text { responses) }\end{array}$} \\
\hline Broad casting & & 85 & 92 & 94 & 90 & \\
\hline Line & Recommendation & 15 & 8 & 6 & 10 & \\
\hline Adoption index & & 15 & 8 & 6 & 10 & Low \\
\hline \multicolumn{7}{|l|}{$\begin{array}{l}\text { 3. Sowing time (\% } \\
\text { responses) }\end{array}$} \\
\hline $2^{\text {nd }}$ Jan. $-3^{\text {rd }}$ Jan. & Late Rabi & - & - & 49 & 16 & \\
\hline $4^{\text {th }}$ Jan.- $2^{\text {nd }}$ Feb. & Recommendation & - & - & 51 & 16 & \\
\hline $2^{\text {nd }} F e b .-3^{\text {rd }} F e b$ & Kharif -1 & 34 & 2 & - & 12 & \\
\hline $4^{\text {th }}$ Feb-2 $2^{\text {nd }}$ March & Recommendation & 66 & 98 & - & 56 & \\
\hline Adoption index & & 66 & 98 & 51 & 72 & Medium \\
\hline \multicolumn{7}{|l|}{$\begin{array}{l}\text { 5. No. of weeding }(\% \\
\text { responses })\end{array}$} \\
\hline One time & & 29 & 44 & 54 & 42 & \\
\hline Two times & Recommendation & 60 & 52 & 44 & 52 & \\
\hline Three times & & 11 & 4 & 2 & 6 & \\
\hline Adoption index & & 91 & 79 & 73 & 81 & High \\
\hline \multicolumn{7}{|l|}{$\begin{array}{l}\text { 6. No. of irrigation }(\% \\
\text { responses) }\end{array}$} \\
\hline Not provided & & 39 & 36 & 32 & 35 & \\
\hline One time & & 57 & 62 & 66 & 62 & \\
\hline Two times & Recommendation & 4 & 2 & 2 & 3 & \\
\hline Adoption index & & 33 & 33 & 34 & 33 & Low \\
\hline \multicolumn{7}{|l|}{$\begin{array}{l}\text { 7. Pest control( } \% \\
\text { responses })\end{array}$} \\
\hline Do not use pesticides & & - & 40 & 34 & 25 & \\
\hline Use pesticides & Recommendation & 100 & 60 & 66 & 75 & \\
\hline Adoption index & & 100 & 60 & 66 & 75 & Medium \\
\hline
\end{tabular}


Adoption of seed and fertilizer by the sampled farmers is presented in Table 4. The recommended seed rate of mungbean is $40 \mathrm{~kg} / \mathrm{ha}$. According to adoption index, it was found that the adoption level of seed was high. The farmers in the study area used lower quantity of urea and TSP and excess quantity of MoP than in recommended doses. Based on the adoption index, urea secured higher adoption level followed by TSP and MoP.

Table 4. Input use and adoption level of mungbean cultivation in different study

\begin{tabular}{|c|c|c|c|c|c|c|}
\hline Inputs & $\begin{array}{l}\text { Recomm- } \\
\text { endation }\end{array}$ & Jessore & Kushtia & Barisal & All areas & $\begin{array}{c}\text { Adoption } \\
\text { level }\end{array}$ \\
\hline Seed & 40 & 35 & 40 & 43 & 39 & \\
\hline Adoption index & & 88 & 100 & 104 & 97 & High \\
\hline Urea & $40-50$ & 34 & 31 & 34 & 33 & \\
\hline Adoption index & & 86 & 82 & 78 & 82 & High \\
\hline TSP & $80-85$ & 62 & 62 & 55 & 60 & \\
\hline Adoption index & & 76 & 81 & 61 & 73 & Medium \\
\hline MP & $30-35$ & 33 & 35 & 30 & 32 & \\
\hline Adoption index & & 108 & 118 & 96 & 107 & Low \\
\hline
\end{tabular}

\section{Profitability of mungbean cultivation}

The cost of mungbean cultivation included all variable cost items like human labour, power tiller, seed, manures, fertilizer, irrigation, insecticide, etc. (Table 5). In case of family supplied inputs, opportunity cost was considered for the study. The cost of land use was calculated on the basis of lease value of land. The costs of mungbean cultivation were Tk. 22689 and Tk. 15564 per hectare on full cost and cash cost basis, respectively. The highest cost was incurred for human labour $(55 \%)$ followed by seed $(10 \%)$, power tiller $(9 \%)$. and fertilizer cost $(8 \%)$. The cost of mungbean cultivation was found highest in Kushtia (Tk. 24418/ha) followed by that in Jessore (Tk 22021/ha) and Barisal (Tk 21638/ha) due to higher cost of fertilizers and land use.

The average yield of mungbean was found to be $1196 \mathrm{~kg}$ per hectare (Table 6). The yield was highest at Jessore $(1211 \mathrm{~kg} / \mathrm{ha})$ followed by Kushtia $(1189 \mathrm{~kg}$ /ha) and Barisal (1187 kg /ha). The gross margin was found Tk $18173 \mathrm{on}$ variable cost basis. Gross margin was highest in Jessore followed by Kushtia and Barisal area. The net return per hectare was Tk 15678. The net return was highest in Jessore (Tk 18016/ha) followed by Barisal (Tk 14554/ha) and Kushtia (Tk 14091/ha) due to higher gross return. Benefit cost ratio was 1.69 and 2.47 on full cost and cash cost basis. 
Table 5. Cost of mungbean cultivation in different study areas.

\begin{tabular}{lccccc}
\hline \multirow{2}{*}{ Items } & \multicolumn{4}{c}{ Cost of production (Tk/ha) } \\
\cline { 2 - 5 } & Jessore & Kushtia & Barisal & All areas \\
\hline Human labour: & $12060(55)$ & $13205(54)$ & $11928(55)$ & $12397(55)$ \\
Family & 2970 & 3325 & 3024 & 3106 \\
Hired & 9090 & 9880 & 8904 & 9291 \\
Power tiller : & $2063(9)$ & $2006(8)$ & $2054(10)$ & $2041(9)$ \\
$\quad$ Owned & 813 & 401 & 308 & 507 \\
$\quad$ Hired & 1250 & 1605 & 1746 & 1534 \\
Seed : & $2221(10)$ & $2420(10)$ & $2495(12)$ & $2378(10)$ \\
$\quad$ Owned & 440 & 488 & 522 & 483 \\
Purchased & 1781 & 1932 & 1973 & 1895 \\
Manures (Owned) & 29 & 80 & 143 & 84 \\
Fertilizers : & $1704(8)$ & $1860(8)$ & $1585(7)$ & $1716(8)$ \\
Irrigation : & $469(2)$ & $850(4)$ & $620(3)$ & $646(3)$ \\
Owned & 94 & 220 & 103 & 139 \\
Hired & 375 & 630 & 517 & 507 \\
Insecticides & $685(3)$ & $543(2)$ & $635(3)$ & $621(3)$ \\
Interest on operating capital & $299(1)$ & $329(1)$ & $307(1)$ & $311(1)$ \\
Fixed cost (FC)* & $2491(12)$ & $3125(13)$ & $1871(8)$ & $2495(11)$ \\
Total cash cost (TCC) & $14979(68)$ & $16450(67)$ & $15360(66)$ & $15564(68)$ \\
Total variable cost (TVC) & $19530(89)$ & $21293(87)$ & $19767(91)$ & $20194(89)$ \\
Total Cost (VC+FC) & $22021(100)$ & $24418(100)$ & $21638(100)$ & $22689(100)$ \\
\hline Note: Bracketed & & &
\end{tabular}

Note: Bracketed figures indicate the percentage of total cost.

* Fixed cost included cost of land use.

Land use cost was calculated on the basis of rental value of land.

\section{Factors of mungbean production}

The maximum likelihood estimates for parameters of the Cobb-Douglas stochastic production frontier for mungbean was presented in Table 7. The empirical results indicated that the coefficients of human labour, seed, fertilizer, power tiller, and irrigation cost were found positive and significant at 1, 1, 1, 5, and 5\% level, respectively. This implies that the aforesaid variables had a significant and positive impact on mungbean yield. Moreover, the coefficients of dummy variables, such as soil type, sowing date, and seed source were also positive and significant at 10,1 , and $1 \%$, respectively. The dummy for sowing date had the largest positive coefficient (0.964) followed by source of seed (0.739) and soil type (0.269). 
Table 6. Profitability of mungbean cultivation in different study areas.

\begin{tabular}{l|c|c|c|c}
\hline \multirow{2}{*}{\multicolumn{1}{c}{ Items }} & \multicolumn{4}{c}{ Study areas } \\
\cline { 2 - 5 } & Jessore & Kushtia & Barisal & All areas \\
\hline Grain yield (kg/ha) & 1211 & 1189 & 1187 & 1196 \\
Price (Tk./kg) & 32.67 & 32.00 & 30.00 & 31.56 \\
Gross return (Tk./ha) & 40037 & 38509 & 36192 & 38367 \\
$\quad 3$ Grain & 39563 & 38058 & 35610 & 37865 \\
$\quad$ By -product & 474 & 451 & 582 & 502 \\
Total cash cost (Tk./ha) & 14979 & 16450 & 15360 & 15564 \\
Total variable cost (Tk./ha) & 19530 & 21293 & 19767 & 20194 \\
Total cost (Tk./ha) & 22021 & 24418 & 21638 & 22689 \\
Gross margin (Tk./ha) & 20507 & 17216 & 16425 & 18173 \\
Net return (Tk./ha) & 18016 & 14091 & 14554 & 15678 \\
Benefit cost ratio: & & & & \\
\multicolumn{1}{c}{ Full cost basis } & 1.82 & 1.58 & 1.67 & 1.69 \\
$\quad$ Cash cost basis & 2.67 & 2.34 & 2.36 & 2.47 \\
\hline
\end{tabular}

\section{Technical efficiency of mungbean farmers}

The estimated coefficient of technical in-efficiency model showed that the coefficient of farmers education, income, and farming experience were negative but significant at $1 \%$ level which implies that technical inefficiency in mungbean production decreases with the increases in farmers education, income, and farming experiences. The coefficient of training on pulse was positive but not significant and on the other hand, the coefficient of extension linkage was negative but not significant (Table 7).

On an average, $67 \%$ farmers of mungbean achieved technical efficiency level of more than $90 \%$. Twenty eight percent farmers' technical efficiency level between 81 and $90 \%$ and the rest 5\% farmers' technical efficiency level less than $80 \%$ (Table 8). In considering locations, farmers in Jessore achieved highest technical efficiency level (94\%) followed by that of Kushtia (73\%) and Barisal $(31 \%)$.

\section{Constraints to mungbean cultivation}

Although mungbean is opined to be a profitable crop in the study areas, there are several constraints to its higher production. The constraints have been presented in Table 9. About $81 \%$ farmers opined disease and pest infestation as a top ranked problem of mungbean cultivation. Other constraints were lack of good quality seed (60\%), lack of knowledge of improved technology (50\%), and excess rainfall after flowering (20\%). 
Table 7. Maximum likelihood estimates of the stochastic Cobb- Douglas frontier production function and technical inefficiency model for mungbean in the study areas.

\begin{tabular}{|c|c|c|c|c|}
\hline Independent variables & Para-meters & Co-efficient & $\begin{array}{l}\text { Standard } \\
\text { error }\end{array}$ & $\mathrm{T}$ - ratio \\
\hline \multicolumn{5}{|l|}{ Stochastic Frontier model } \\
\hline Constant & $\beta_{0}$ & $0.407 * * *$ & 0.411 & 9.90 \\
\hline Human labor (Man-days/ha) & $\beta_{1}$ & $0.306 * * *$ & 0.731 & 4.18 \\
\hline Power tiller cost (Tk./ha) & $\beta_{2}$ & $0.497 * *$ & 0.244 & 2.03 \\
\hline Seed (kg/ha) & $\beta_{3}$ & $0.263 * * *$ & 0.458 & 5.74 \\
\hline Fertilizer (kg/ha) & $\beta_{4}$ & $0.118 * * *$ & 0.350 & 3.37 \\
\hline Farm yard manure (kg/ha) & $\beta_{5}$ & 0.222 & 0.196 & 1.13 \\
\hline Irrigation cost (Tk./ha) & $\beta_{6}$ & $0.395 * *$ & 0.190 & 2.07 \\
\hline Insecticides cost (Tk./ha) & $\beta_{7}$ & -0.200 & 0.217 & -9.18 \\
\hline $\begin{array}{l}\text { Dummy for land type }(1=\text { MHL, } 0= \\
\text { otherwise) }\end{array}$ & $\eta_{1}$ & -0.169 & 0.141 & -1.19 \\
\hline $\begin{array}{l}\text { Dummy for soil type }(1=\text { Sandy } \\
\text { loam, } 0=\text { otherwise })\end{array}$ & $\eta_{2}$ & $0.269 *$ & 0.140 & 1.91 \\
\hline $\begin{array}{l}\text { Dummy for sowing date }(1= \\
\text { Optimum, } 0=\text { otherwise })\end{array}$ & $\eta_{3}$ & $0.964 * * *$ & 0.168 & 5.72 \\
\hline $\begin{array}{l}\text { Dummy for seed source }(1= \\
\text { Agricultural office } / \mathrm{BARI}, 0= \\
\text { otherwise }\end{array}$ & $\eta_{4}$ & $0.739 * * *$ & 0.148 & 4.96 \\
\hline \multicolumn{5}{|l|}{ Technical Inefficiency Model } \\
\hline Constant & $\delta_{0}$ & $0.117 * * *$ & 0.380 & 3.08 \\
\hline Farmers age (Years) & $\delta_{1}$ & -0.645 & 0.131 & -0.49 \\
\hline $\begin{array}{l}\text { Farmers education (year of } \\
\text { schooling) }\end{array}$ & $\delta_{2}$ & $-0.591 * * *$ & 0.346 & -2.47 \\
\hline Family size (person/ hh) & $\delta_{3}$ & -0.150 & 0.104 & -1.44 \\
\hline Farmers income & $\delta_{4}$ & $-0.101 * * *$ & 0.363 & -2.77 \\
\hline Pulse farming experience (years) & $\delta_{5}$ & $-0.514 * * *$ & 0.241 & -2.13 \\
\hline $\begin{array}{l}\text { Dummy for extension linkage }(1= \\
\text { yes, } 0=\text { otherwise })\end{array}$ & $\delta_{6}$ & -0.284 & 0.397 & -0.71 \\
\hline $\begin{array}{l}\text { Dummy for pulse training }(1=\text { yes, } \\
0=\text { otherwise })\end{array}$ & $\delta_{7}$ & 0.351 & 0.277 & 1.26 \\
\hline \multicolumn{5}{|l|}{ Variance Parameters } \\
\hline Sigma- squared & $\sigma^{2}$ & $0.111 * * *$ & 0.274 & 4.05 \\
\hline Gamma & $\Gamma$ & $0713 * * *$ & 0.152 & 4.67 \\
\hline Log likelihood function & & - & 312.33 & \\
\hline
\end{tabular}

Note: $* * *, * *$ and $*$ indicate significance at 1,5 and $10 \%$ level of probability, respectively. 
Table 8. Distribution of sample farmers by level of technical efficiency.

\begin{tabular}{c|c|c|c|c|c|c|c|c}
\hline \multirow{2}{*}{$\begin{array}{c}\text { Technical } \\
\text { efficiency } \\
\text { level (\%) }\end{array}$} & \multicolumn{2}{|c|}{ Jessore } & \multicolumn{2}{c|}{ Kushtia } & \multicolumn{2}{c|}{ Barisal } & \multicolumn{2}{c}{ Total } \\
\cline { 2 - 8 } farmers & $\%$ & $\begin{array}{c}\text { No. of } \\
\text { farmers }\end{array}$ & $\%$ & $\begin{array}{c}\text { No. of } \\
\text { farmers }\end{array}$ & $\%$ & $\begin{array}{c}\text { No. of } \\
\text { farmers }\end{array}$ & $\%$ \\
\hline $71-80$ & - & - & - & - & 14 & 16 & 14 & 5 \\
$81-90$ & 6 & 6 & 26 & 27 & 48 & 53 & 80 & 28 \\
$91-100$ & 92 & 94 & 69 & 73 & 28 & 31 & 189 & 67 \\
All level & 98 & 100 & 95 & 100 & & 100 & 283 & 100 \\
\hline
\end{tabular}

Table 9. Constraints of mungbean cultivation.

\begin{tabular}{|c|c|c|c|c|c|}
\hline Constraints & Jessore & Kushtia & Barisal & All & Rank \\
\hline 1. Lack of good quality seed & 51 & 64 & 64 & 60 & 2 \\
\hline 2. Disease and pest infestation & 97 & 75 & 72 & 81 & 1 \\
\hline $\begin{array}{l}\text { 3. Excess rainfall after } \\
\text { flowering }\end{array}$ & 20 & 36 & 22 & 26 & 4 \\
\hline $\begin{array}{l}\text { 4. Lack of knowledge of } \\
\text { improved technology }\end{array}$ & 43 & 50 & 56 & 50 & 3 \\
\hline
\end{tabular}

\section{Conclusions and Recommendations}

It may be concluded from the above discussion that the level of adoption of mungbean technologies are very much encouraging. The adopted promising mungbean varieties are BARI Mungbean-5 and BARI Mungbean-4. The level of adoptions of the crop management technologies, such as weeding, use of urea, and seed rate are also very high. Economic analysis of mungbean production reveals that it is a profitable crop to most of the farmers. They could increase mungbean yield by spending more on tillage operations, crop management (Human labour), seed, fertilizers, and irrigation since these inputs had significant and positive impact on yield. About $67 \%$ mungbean farmers could achieve $90 \%$ technical efficiency implying that they could increase mungbean productivity through increasing their technical efficiencies in many issues, such as education, income, and farming experience. Although mungbean is a profitable crop, its growers faced different constraints, such as disease and pest infestation, lack of good quality seed, and lack of knowledge of improved technology.

The following recommendations are given based on the findings of the present study.

- Improved variety of mungbean seed should be made locally available to the farmers at proper time. For this reason, government should encourage BADC and private seed companies for producing improved mungbean seed and supply them at reasonable price to the farmers. 
- Regular training on mungbean cultivation should be organized by the Department of Agricultural Extension (DAE) in association with BARI for mungbean farmers to develop their technical knowledge about improved cultivation practices of mungbean.

- Motivational campaign through distributing booklets and other supporting materials to the farmers and extension personnel about the improved technologies of mungbean.

- More intensive research should be undertaken by the scientists of BARI and BINA to develop disease and insect-pest resistant mungbean varieties in future.

\section{References}

Afzal, M. A. and M. A. Bakar. 2004. Experience of legume promotion project in Bangladesh- the LBMDPP. Proceeding of a project inception workshop, Bangladesh Agricultural Research Institute, Joydebpur, Gazipur, Bangladesh.

Abedin, M. Z. and M. Anwarul. 1991. Prospects of increasing pulse production through improved cropping systems. In: Proceedings of the $2^{\text {nd }}$ National Workshop on Pulses, BARI, Joydebpur, Gazipur, 65-73.

AVRDC (Asian Vegetable Research and Development Centre). 1988. Mungbean Proceedings of the First International Mungbean Symposium Shanhua, Taiwan.

BBS (Bangladesh Bureau of Statistics). 2011. Agricultural Statistics of Bangladesh, Statistics Division, Ministry of Planning, Government of the Peoples Republic of Bangladesh, Dhaka.

Coelli, T. J. and G. E. Battese. 1996. Identification of factors which influence the technical inefficiency of Indian farmers. Australian Journal of Agricultural Economics 40(2), 103-128.

Islam, Q. M. S., M. A. M. Miah and Q. M. Alam. 2007. Productivity and Profitability of mungbean cultivation in selected areas of Bangladesh. Annual Report, AED, BARI, Gazipur.

Rahman M. M. 1998. Technology information on lentil, blackgram, and mungbean lecture note, Training Workshop on Lentil, Blackgram and Mungbean at BARI, Joydebpur, Gazipur, February. Pp. 22-23.

Senanayake, L., D. P. Knievel and S. E. Stevena. 1987. Nodulation and symbiotic nitrogen fixation of cowpea (Vigna unguiculata L.). Plant Soil 99: 435-439.

Sharma, S. N. and R. Prasad. 1999. Effects of sesbania green manuring and mungbean residue incorporation of productivity and nitrogen uptake of a rice- wheat cropping system. Bioresource Technology 67(2): 171-175.

Zapata, F., S. K. A. Danso, G. Hardarson and M. Fried. 1987. Nitrogen fixation and translocation in field-grown fababean. Agronomy Journal 79: 505-509. 